\title{
PRE-EXISTING AUTOIMMUNE THYROID DISEASE (AITD) MAY INFLUENCE THE COURSE OF THE DISEASE IN DIFFERENTIATED THYROID CARCINOMA (DTC) PATIENTS
}

\author{
A. Athanasiadou, K. Saltiki, G. Rentziou, G. Papageorgiou, E. Anastasiou, M. Alevizaki
}

${ }^{1}$ Endocrine Unit, Department of Clinical Theurapeutics, Alexandra Hospital, Athens, Greece

\section{Introduction - Aim of the study}

DTC has generally a good prognosis and is associated with prolonged survival.

A minority of patients may have persistent disease and rarely aggravation during $f / u$.

One of the risk factors associated with the prognosis of the disease is the previous history of autoimmune thyroid disease (AITD)

Autoimmmunity has been associated with better prognosis although not consistently Kim et al. 2009, Gupta et al. 2001, Loh et al. 1999

Muzza et al. 2010, Del Rio et al. 2008, Pacini et al. 1988

We investigated whether preexisting autoimmunity may influence the persistence of disease in a cohort of patients who had undergone ablation with 1131 and are followed up in a single centre in Greece.

\section{Patients - Methods}

903 DTC patients were referred to our center from 1968-2012

541 underwent thyroid remnant ablation

$\checkmark 22.4 \%$ males

$\checkmark$ They were followed-up for $1-44$ years $(7.9 \pm 8.4 \mathrm{yrs})$

A. $344(65.6 \%)$ : remission (12 month stimulated $\mathrm{Tg} \leq 1.0 \mathrm{ng} / \mathrm{ml})$

B. $197(36.5 \%)$ : persistence (12 month stimulated $\mathrm{Tg}>1 \mathrm{ng} / \mathrm{ml})$. Most of group B underwent repeated treatments:>1 surgery and/or repeat ${ }^{131}$ administration.

Group B were divided in 4 subgroups:

Group1: Patients who finally showed remission (39.1\%)

Group2: Persistently low-Tg ( $\leq 5 \mathrm{ng} / \mathrm{ml})$ during f/u \& no clinical aggravation $(23.9 \%)$

Group3: Persistently high-Tg (>5ng/ml, \& no clinical aggravation (25.4\%)

Group4: Clinical aggravation (11.7\%), (Fig 1)
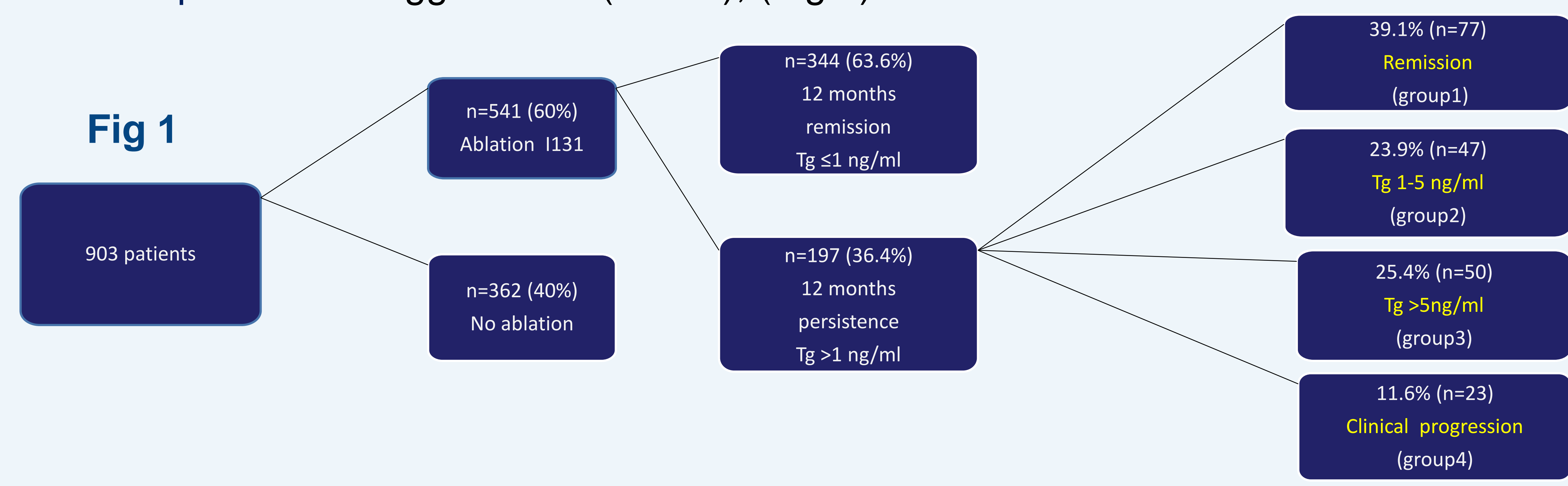

\section{Results in patients who underwent ablation with I'131 $(n=541)$}

- Male patients had more frequently disease persistence than females $(p=0.008$, table 1$)$

- Patients with 12 month remission of disease had more frequently history of autoimmunity and thyroid autoantibodies at diagnosis ( $p=0.008$, fig 2,3 )

Table 1. Disease progression according to gender

\begin{tabular}{|c|c|c|}
\hline & REMISSION & PERCISTENCE \\
\hline MALES & $63.3 \%$ & $34.7 \%$ \\
\hline FEMALES & $81.5 \%$ & 18.6 \\
\hline
\end{tabular}
\section{Results in patients who und
(during the 12-month Tg
Group1 had more frequently positive history of AITD and
positive thyroid autoantibodies at diagnosis} $(p=0.003$, fig 2,3$)$.

- Age at diagnosis, tumor size and Tg levels at the time of the $1^{\text {st }}$ ablation were higher in groups 3 and 4 $(p<0.04$, Mann-Whitney, table 5).

- Group1 had more frequently microDTCs $(<1.0 \mathrm{~cm})$, less frequently lymph-node involvement, soft tissue involvement and distant metastases at diagnosis $(p=<0.003)$.

- More aggressive histological type was more frequently observed in group4 $(p<0.001)$.

- No differences in multifocality, family DTC history and type of first surgery were observed between groups.
Table 2, 3. Disease progression according to AITD history and preoperative ThAb positivity

\begin{tabular}{|l|c|c|c|}
\hline & $\begin{array}{c}\text { AITD HISTORY } \\
\text { POSITIVE }\end{array}$ & $\begin{array}{c}\text { AITD HISTORY } \\
\text { NEGATIVE }\end{array}$ & $P$ \\
\hline REMISSION & $95.5 \%$ & $76.2 \%$ & \\
\hline PERCISTENCE & $4.5 \%$ & $21 \%$ & 0.001 \\
\hline & ThAb positive & ThAb negative & $P$ \\
\hline REMISSION & $96.9 \%$ & $67.9 \%$ & \\
\hline PERSISTENCE & $3.1 \%$ & $28.3 \%$ & 0.001 \\
\hline
\end{tabular}

Table 4. Clinical and histological characteristics according to AITD history

\begin{tabular}{|l|c|c|c|} 
& $\begin{array}{c}\text { AITD HISTORY } \\
\text { POSITIVE }\end{array}$ & $\begin{array}{c}\text { AITD HISTORY } \\
\text { NEGATIVE }\end{array}$ & $P$ \\
\hline MicroPTC & $36.9 \%$ & $20.2 \%$ & 0.003 \\
\hline Multifocal & $56.2 \%$ & $44.5 \%$ & 0.041 \\
\hline Capsular invasion & $65.4 \%$ & $64.6 \%$ & 0.5 \\
\hline Soft tissue involvement & $8.7 \%$ & $10.3 \%$ & 0.4 \\
\hline Lymph-node mets & $35 \%$ & $31 \%$ & 0.28 \\
\hline Distant mets at diagnosis & $0.8 \%$ & $3.1 \%$ & 0.17
\end{tabular}
g-stimulation test: Thyroglobulin $>1.0 \mathrm{ng} / \mathrm{ml})(\mathrm{n}=197)$

Patients with persistent disease at $1 \mathrm{yr}$ : Disease progression according to ThAb positivity at diagnosis

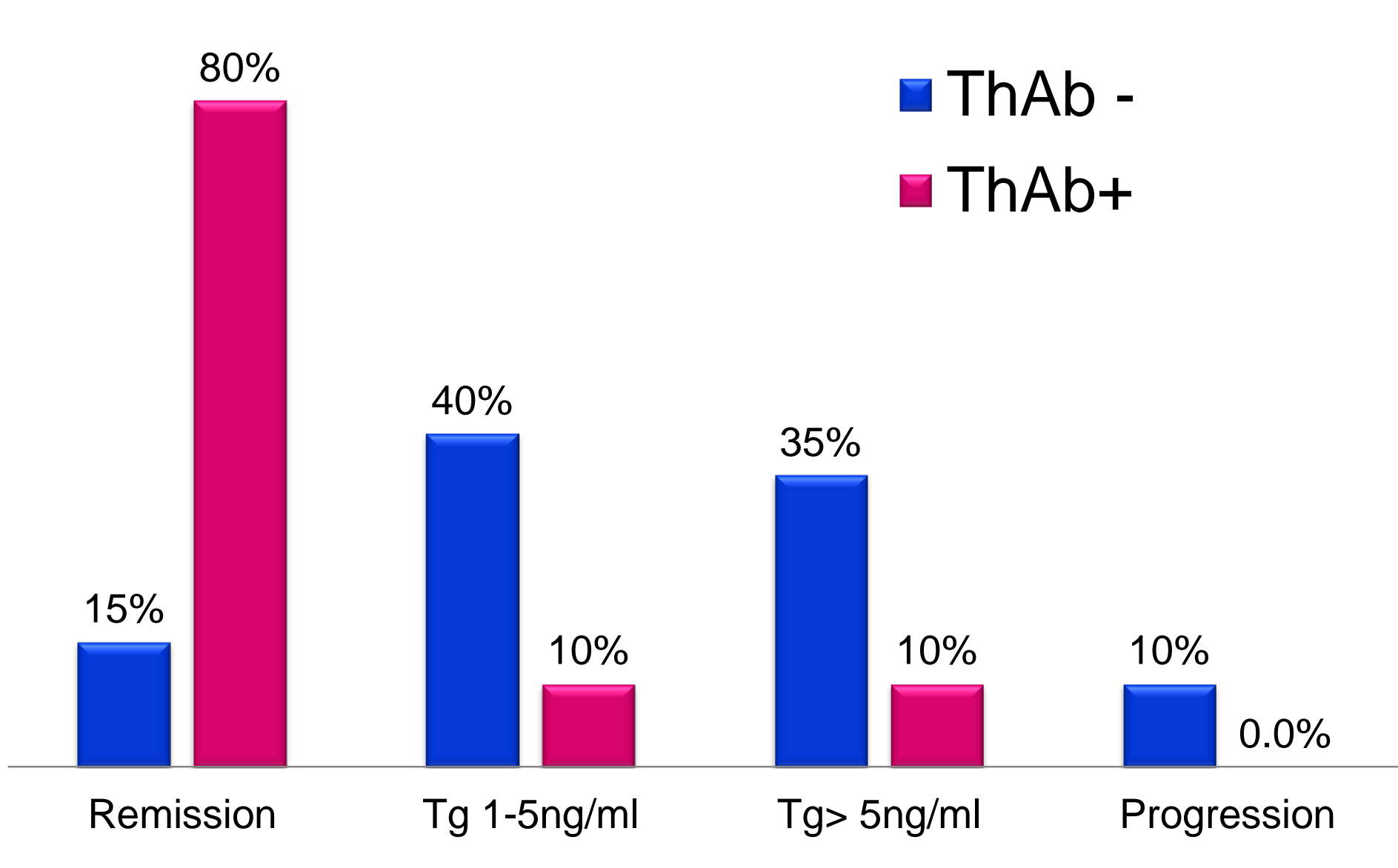

Patients with persistent disease at $1 \mathrm{yr}$ Disease progression according to

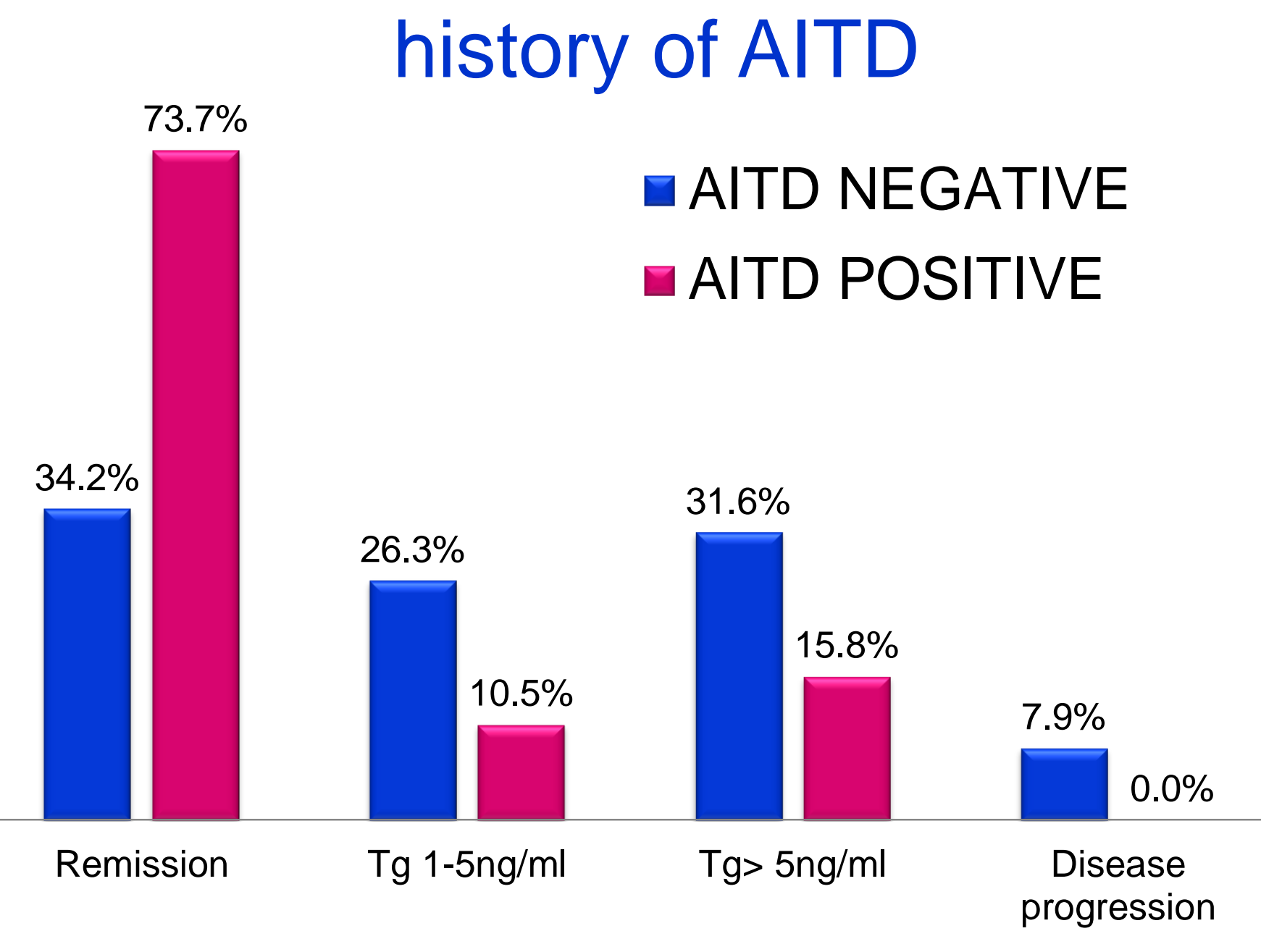

Table 5. Age at diagnosis and tumor size at the time of the 1st ablation in the 4 groups

\begin{tabular}{|c|c|c|c|c|c|}
\hline & REMISSION & TG $1-5 \mathrm{ng} / \mathrm{ml}$ & TG $>5 \mathrm{ng} / \mathrm{ml}$ & CLINICAL AGGRAVATION & $P$ \\
\hline AGE (YEARS) & $41.89 \pm 13.52$ & $35.85 \pm 12.9$ & $40.41 \pm 17.2$ & $49.9 \pm 20.9$ & 0.005 \\
\hline TUMOUR SIZE (CM) & $1.64 \pm 1.0$ & $1.69 \pm 0.9$ & $1.96 \pm 1.56$ & $2.8 \pm 1.65$ & 0.024 \\
\hline
\end{tabular}

\section{Conclusions}

Except from the classical predisposing factors (tumor size, histological and clinical findings) preexisting AITD is associated with increased frequency of remission in patients with DTC. Similar results have been reported using tissue markers of autoimmunity. (Matsubayashi et al. 1995, Singh et al. 1999) SUGGESTED MECHANISMS

- Cytokines may play a favorable role in the development of DTC

- Lymphocytic infiltration itself may be associated with decreased disease spread

- The autoantibodies may be recognising and attacking malignant cells

(Cunha et al. 2011, Giordano et al. 1997, Bagnasco et al. 1989, Kimura et al. 1992) 